\title{
Implementation Analysis of Trans Mebidang Program in Transportation Mode Services, North Sumatera (Comperative Study of Medan City)
}

\author{
Agussani \\ Universitas Muhamadiyah Sumatera Utara, Indonesia \\ agussani@umsu.ac.id
}

\section{Abstract}

Trans Mebidang is a bus rapid transit system in the province of North Sumatra that operates in Medan, Binjai, and Deli Serdang districts. Operated by Perum Damri, this BRT has been operating at the end of 2015, after being delayed from the 2013 target, with a fleet of 30 air-conditioned buses spread across two corridors, in its journey from 2015-2020 this rapid bus has become the capital of the capital mode. for the people of Medan City, Binjai and Deli Serdang. This study aims at how the implementation of the Trans Mebidang Program in Transportation Mode Services in North Sumatra (Comparative Study of Medan City). This study uses a qualitative analysis using the P4 analytical system approach which is planning, regulation, supervision and control. From the research results obtained the status of Medan, Binjai and Deli Serdang (Mebidang) As a National strategic area and strengthened by the existence of the Governor of North Sumatra Governor Regulation Number 31 of 2014 concerning Road-based Mass Public Transport Services in Urban Areas of Medan, Binjai and Deli Serdang, in program implementation has been running but not yet effective, efficient and productive. Because there are still many main and supporting infrastructure facilities that are still lacking in supervision and control. Recommendations and suggestions in this study Local Government which is integrated with mass transportation program is expected to work hand in hand to strengthen the North Sumatra government program, it is time for the Regional Government to develop spatial planning by strengthening vehicle ratios and strengthening SOP (Standard Operating Procedure) that must be strengthened and actually.
\end{abstract}

\section{Keywords}

trans mebidang program; transportation service

\section{Introduction}

Transportation at this time has become a basic need for community activities, especially the activities of the people of North Sumatra. These activities make transportation an important choice with an increasing number of populations using transportation modes, especially public transportation.

In the course of transportation, it is really needed an affective policy and management. We often hear this management in terms of Traffic Management and Mode of Transportation. Traffic management includes the Planning, Arrangement, Supervision and Control Processes.

As stipulated in Law Number 22 Year 2009, a public transportation should meet the needs of being safe, safe, convenient, and affordable. Besides that, the price should also be affordable. As stated by Okeke et.al., (2015) that lower price paid by consumerscan positively affect the consumers' customer satisfaction. This effort is reinforced by Regulation of the Minister of Transportation of the Republic of Indonesia No. 29 of 2015 on the Amendment of the Minister of Transportation Regulation No. 98 of 2013 on Minimum 
Service Standards of Transportation of People with Public Vehicles in Route. It is stated that the obligations of public transport companies are to meet minimum service standards, including Security, safety, comfort, affordability, equality, and order. (Sukesi, 2018)

According to Sani Zulfiar (2020: 38) policies must be synchronized with order, smoothness and orientation towards safety. This is seen from the aspects: first, Increasing the capacity of roads, intersections, and / road networks. Second, giving priority to certain types of vehicles or road users. Third, the adjustment between travel requests and certain service levels by considering intra and intermodal integration. Fourth, Determination of traffic circulation, prohibitions or orders for road users.

Then in the implementation of transportation the local government must also pay attention to these transportation activities as an effort in creating "Good Transportation" by considering the following basic aspects: a). Route (network) consisting of origin, destination and trajectory, b). Infrastructure (infrastructure) in accordance with the transportation used, c). Tools for moving, d). Operational processes for managing vehicle operations so that they are as efficient as possible, e). Implementing regulations governing the use of infrastructure by means of many uses at the same time in one place or space, f). Supervision: so that the use of infrastructure runs in an orderly manner in accordance with the regulations issued, $\mathrm{g}$ ). Pekasanaan (transport entrepreneur / organizing agency): the party that provides the means for a transfer mechanism, usually referred to as a public transport entrepreneur, $\mathrm{h}$ ). Passenger (consumer): who requires a conveyance to facilitate its transfer and to make it faster to reach the desired destination, i). Parties affected by transportation (environment): parties that can interfere or be disrupted in peruses movement or operation of facilities According to Sani Zulfiar (2010: 12)

Trans Mebidang is a bus rapid transit system in the province of North Sumatra that operates in Medan, Binjai, and Deli Serdang districts. Operated by Perum Damri, the BRT has been operating at the end of 2015, after being delayed from the 2013 target, with a fleet of 30 air-conditioned bus units spread over two corridors, namely:

Table. 1 Trans Bulk Lines and Routes Mebidang

\begin{tabular}{cll}
\hline No & \multicolumn{1}{c}{ Corridor } & \multicolumn{1}{c}{ Route } \\
\hline 1 & Medan-Binjai & Binjai Terminal, \\
& Corridor & Jalan Soekarno- \\
(corridor I), & Hatta, Jalan Gatot \\
& along 23 km & Subroto, Jalan \\
and takes & Iskandar Muda, \\
about 90 & Jalan Gajah \\
minutes & Mada, Jalan S \\
& & Parman, Jalan \\
& & Raden Saleh, \\
& & Jalan Balai Kota, \\
& & Jalan Stasiun, \\
& & Jalan MT \\
& & Haryono, Jalan \\
& & Sutomo, Pusat \\
& & Pasar (Medan) \\
& &
\end{tabular}




\begin{tabular}{lll}
\hline 2 & $\begin{array}{l}\text { Corridor } \\
\text { Medan-Deli } \\
\text { Serdang } \\
\text { (corridor II), }\end{array}$ & $\begin{array}{l}\text { Market Center } \\
\text { (Medan), Jalan }\end{array}$ \\
Sutomo, Jalan \\
and travel \\
time of 100 & Jemerdekaan, \\
minutes & Yamin, Jalan \\
& Stasiun, Jalan MT \\
& Haryono, Jalan \\
& Cirebon, Jalan \\
& Sisingamangaraja, \\
& Jalan Medan, \\
& Terminal Lubuk \\
& Pakam \\
\hline
\end{tabular}

Source: North Sumatra Transportation Agency, 2019

According to North Sumatra Governor Regulation No. 31 of 2014 concerning Roadbased Mass Public Transport Services in the Urban Areas of Medan, Binjai and Deli Serdang. That the Medan, Binjai and Deli Serdang (Mebidang) Regions are one of the National Strategic Areas (KSN), therefore, it is necessary to stipulate Regulations on Mass Public Services Based on Medan, Binjai and Deli Serdang Urban Roads.

The statement was reaffirmed in Article 1 General Provisions namely Mass Public Transport in Medan, Binjai, Deli Serdang Urban Areas, hereinafter referred to as Trans Mebidang BRT, is a special road-based mass transit system with a buy-service system in Medan, Binjai, Deli Serdang (Mebidang) by using a bus on a designated route / lane.

This special road-based mass transit system with a service purchase system is the implementation of service objects whose orientation is to the satisfaction aspect whether they already have criteria in traffic management and the need for regional spatial planning. And whether this policy is in accordance with the activities of the Planning, Regulating, Supervising and controlling processes.

Therefore, this research will look at conformity with the activities of good modes of transportation services towards the aspects of public service.

In this case the researcher will conduct a study entitled "Analysis of the Implementation of the Trans Mebidang Program in Transportation Mode Services in North Sumatra (Comparative Study of Medan City)"

\section{Research Method}

This research uses qualitative research methods and is descriptive in nature. Called qualitative because researchers directly descend the spaciousness to examine. Field research is carried out by digging data sourced from the research location. While it is descriptive because this research is intended to describe the complete state of the object under study. Location selection is done by determining based on community social needs activities. Then the location selection category was determined by Medan City as a dense activity accessibility in its implementation. 


\section{Discussion}

In elaborating the results and discussion the researchers used the concept of P4 namely Planning, Arrangement, Supervision and Control. The concept is an effort in the direction of "Good Transportation"

\section{a. Planning Aspects}

In an effort to interpret the needs of the community in making the field a metropolitan area. So the regional government followed up with the Central Government decree that made Medan, Binjai and Deli Serdang as National Strategic Areas (KSN) by forming Mebidangro and Mebidang mass transportation modes. Effective Planning Process According to Sani Zulfiar (2010: 12) is:

a) Inventory and evaluate the level of service. Intentrating is intended to know the level of service on each road section, including intersections. in this case the city of Medan is still experiencing problems in determining the problem referred to roads. The purpose of the service level in this provision is the ability of roads and intersections to accommodate traffic. Because after all roads must be balanced with the number of vehicles that are calculated on a daily basis. Vehicle ratios increase each year, this is not supported by roads. Medan City Is Constrained in Providing Roads.

b)Determine the desired level of service (General road transport network plan: road use, capacity and characteristics: road class: traffic characteristics. Environmental aspects, social and economic aspects). Until now the city of Medan with the development of Spatial Planning and Transportation is still in the search for effective provisions, why is this determination not yet strengthened with the provisions that it seems like a Roadworthy Bus (Buses that have met the roadworthy requirements and stated with proof of passing the test) are still many in the city Terrain that is not operational is still running, Time Table, Round Trip, Headway (H), Capacity, Speed are still in significant problems.

c) Prepare a plan and program for implementing it. The purpose of the plan and implementation includes: determining the desired level of service on each road and intersection: proposed traffic rules that will be set on each road and intersection: proposed procurement and installation and 9 maintenance of traffic signs, road markings, traffic signaling tools, and tools for controlling and securing road users: proposed activities or actions both for the purpose of preparation and counseling to the community. Here are the problems that occur in Medan including:

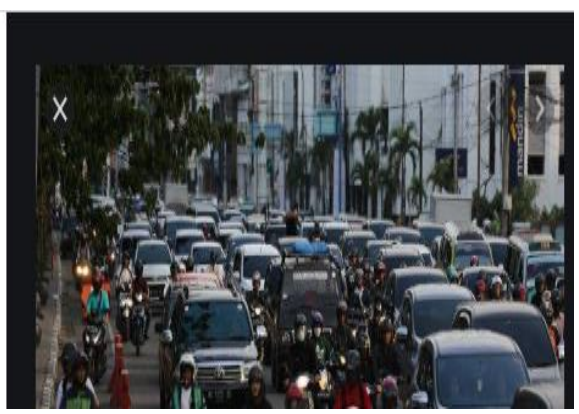

Figure.1 Traffic Congestion at the Center Medan city 


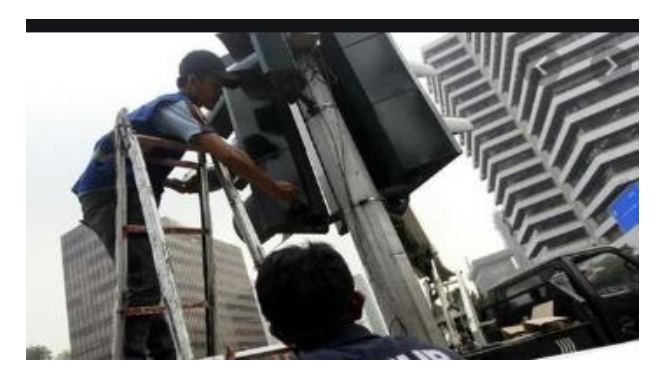

Figure.2 Traffic Lights Broken

\section{b. Regulatory Aspects}

Arrangement on roads is an activity for traffic on certain networks or road sections, including in this case the determination of traffic circulation, determination of maximum and or minimum speeds, restrictions on road use, restrictions and orders for road users contained in road signs markers. This has been determined and regulated by the existence of the Trans Mass route in the Corridor 1 and Corridor 2 routes.

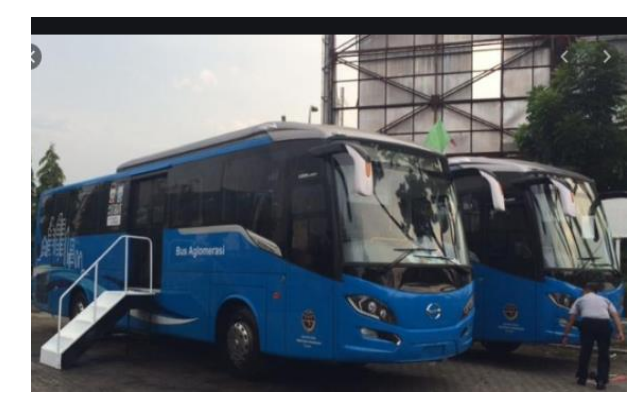

Figure.3 Stop in Binjai

However, there are also some things that are still experiencing problems with this mass BRT trip, including the use of maximum and minimum speeds. This happens because of congestion and roads in the city of Medan with many private vehicles and other public vehicles. So that this mass Trans is not yet a solution in overcoming city congestion because people are still minimal in using this public transportation. Then this BRT still does not have its own road section so it is often trapped too handicapped and many people are reluctant to use it and have other conventional transportation.

\section{c. Supervision Aspect}

In this supervision aspect, there are several aspects in the regulation including:

1) Monitoring and evaluating the implementation of traffic policies. Monitoring and assessment activities are intended to determine the effectiveness of the policy to be determined. Monitoring activities include an inventory of traffic policies that apply to roads, the number of violations and corrections that have been carried out by those violators.

2) Corrective actions towards the implementation of traffic policies. Corrective action is intended to ensure the achievement of specified service level targets. In the supervision seen in this study include: roads and bus stops that are still experiencing problems and have been functionalized by the community because of inadequate supervision and bad habits in the use of public facilities including: 


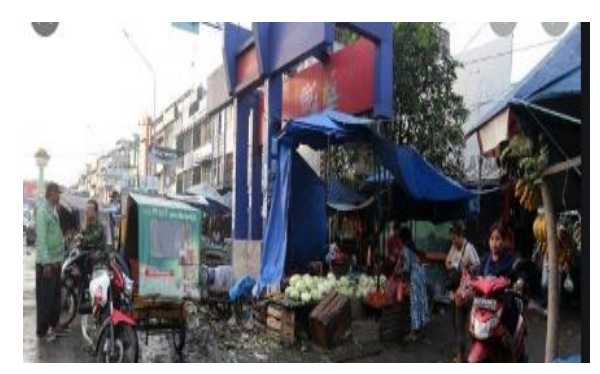

Figure.4 Bus stop in the middle of a traditional market

In the above case, bus stops are in the traditional market crowd in Medan City. This has become one of the ineffectiveness in using bus stops as a convenient, safe and clean stop.

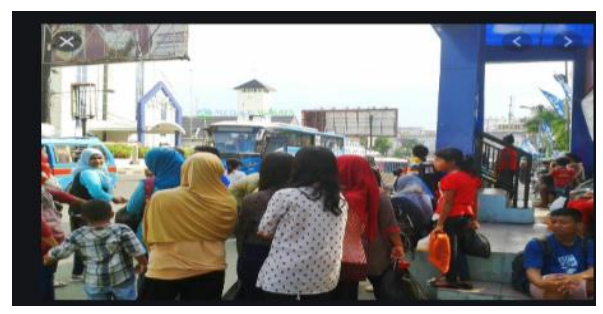

Figure.5 The community is waiting for transportation

In the above activity, we can see many people choosing to wait for transportation below rather than at the stop and they prefer to use other public transportation.

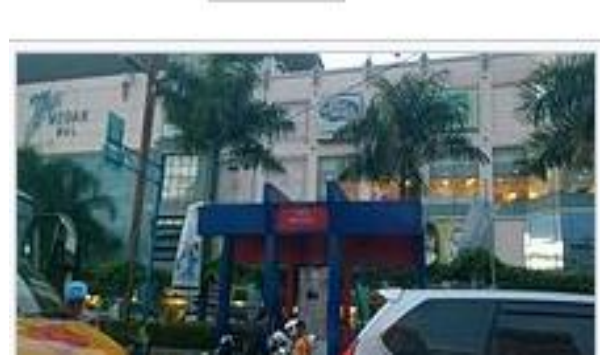

Figure.6.Trans Mebidang bus stop in front Medan Mall, Jalan MT Haryono.

In the above case, there is a deserted bus stop of this transportation capital passenger. It can also be seen that this bus stop is widely used by people for sleeping, eating and activities that do not reflect cleanliness as well. The enthusiasm of the people to use this transportation is still low.

\section{d. Control}

In transportation, giving directions and instructions in implementing traffic policies to the driver.

1) Provision of directives or instructions in this provision in the form of stipulation or provision of guidelines and procedures for the purposes or provision of guidelines and procedures for the purposes of implementing traffic management, with the aim of achieving uniformity in their implementation and can be carried out accordingly to guarantee the achievement of the level of service set. 
2) Providing guidance and counseling to the public regarding community rights and obligations in implementing traffic policies.

In this aspect of control, the researcher sees some vulnerable controls that must be paid close attention to, including in the ticket payment process, the use of uniforms for officers, socialization about service and hospitality and other aspects of hygiene. Then also patience in traffic, prioritizing the implementation of SOP (Operational Standards that are effective and effective).

\section{Conclusion}

Based on the results of the statement above the conclusions of this study are as follows:

1) Planning Aspects: Mass Transportation Planning Aspects This field is quite good, reinforced with the status of Medan, Binjai and Deli Serdang (Mebidang) as a National strategic area and strengthened by the existence of the Governor Regulation North Sumatra Governor Regulation Number 31 of 2014 concerning Mass-based Public Transport Services Roads in the Urban Areas of Medan, Binjai and Deli Serdang.

2) Regulatory Aspects: This aspect of the Regulations carried out by the Government of North Sumatra through the Department of Transportation is quite good, but not yet effective. This is reflected by the absence of specific arrangements for road sections / special lanes, given the relatively small possibility of road widening in Medan City.

3) Supervision Aspect: Supervision in this case is not only for the mode of transportation, but also other supporting facilities such as: bus stops, passengers, officers and others. Because in its implementation the supervision of facilities and infrastructure of this transportation mode is still weak.

4) Control Aspects: These aspects have an "Leading sector" effort at play. Especially giving a good understanding to drivers, officers and passengers about good public service management by taking into account regional assets.

\subsection{Suggestion}

1) The Regional Government which is integrated with the mass transportation program is expected to work hand in hand to strengthen the North Sumatra government program. Because after all make this program and this policy as a form of need and good mindset in the management of regional assets. Good planning with aspects of creating satisfaction with the community.

2) It is time for the Regional Government to develop spatial planning by strengthening the ratio of vehicles. Because after all the amount of transportation is not a solution but good transportation is what provides a good level of service.

3) SOP (Standard Operating Procedure) must be strengthened and implemented in accordance with the Governor's instructions through the North Sumatra Governor's Regulation Number 31 of 2014 concerning Road-based Mass Public Transportation Services in Medan, Binjai and Deli Serdang Urban Areas about Time Tables, Round Trips, Headways ( H), Capacity, Speed and decent operation. 


\section{References}

Dinas Perhubungan Propinsi Sumatera Utara, (2016), Panduan Angkutan Umum Perkotaan, Medan

Direktorat Jenderal Perhubungan Darat, (2002), Panduan Pengumpulan Data Angkutan Umum Perkotaan, Jakarta.

Frids. (2002) .Evaluasi Tarif Angkutan Umum Lintas Magelang-Ngluwar Propinsi Jawa Tengah,Thesis S2 Fakultas Teknik, ITB,Bandung

Gunawan, S. (2004) .Analisis Tarif Berdasarkan Biaya Operasional Kendaraan,Tingkat Kemampuan Dan Kemauan Membayar Penumpang,Tugas Akhir S1 Fakultas Teknik UMS, Surakarta

Gustina, S. B. (2015). Angkutan Umum yang Baik di Jababodetabek.

Peraturan Gubernur Sumatera Utara Nomor 31 Tahun (2014) Tentang Pelayanan Angkutan Umum Massal berbasis Jalan di Wilayah Perkotaan Medan, Binjai dan Deli Serdang. Bahwasannya Kawasan Medan, Binjai dan Deli Serdang (Mebidang)

Rahardjo Adisasmita and Sakti Adji Sasmita. (2011).Manajemen Transportasi Darat, Graha Ilmu.Yogyakarta

Sugiyono. (2010) Metode Penelitian Administrasi, Alfabeta, Bandung.

Sikesi. (2018). Service Quality in Public Transport Services of the Provicial Intercity Transportation (AKDP) in East Java Indonesia. Budapest International Research and Critics Institute (BIRCI-Journal), p. 161-169.

Zulfikar Sani. (2012).Trasnportasi Suatu Pengantar, Universitas Indonesia, Jakarta.

Wijaya C. (2009). Makalah Perencanaan Angkutan Umum, Sipil UI 